\title{
PERFORMANCE OF CONCRETE ARMOUR UNITS OF BREAKWATERS IN INDIA - A REVIEW
}

\author{
Apurva M. Kudale \\ Assistant Professor, Department of Civil Engineering, \\ Vishwakarma Institute of Information Technology, Pune, India
}

\section{D. Kudale}

Assistant Professor, Department of Civil Engineering, Vishwakarma Institute of Information Technology, Pune, \& Former Additional Director, Central Water and Power Research Station, Pune, India

\section{Dr. P. B. Kulkarni}

Professor, Department of Civil Engineering, Vishwakarma Institute of Information Technology, Pune, India

\begin{abstract}
Most of the breakwaters of the major, intermediate and minor ports as well as fishing harbours in India are constructed as flexible rubblemound structures, armoured with quarry stones or artificial concrete armour units. Tetrapods, Dolosse and Cubes are common concrete armour units, which are to be used in double layer in the armour of the rubblemound structures. Development of deep water ports in India has necessitated the designs involving lesser costs. In this context, use of single layer armour units on steeper slopes is inevitable. Single layer armour units like Accropode and Core-loc have also been used for a few breakwaters. Tetrapods are more popular in India in comparison with other armour units. Rubblemound breakwaters constructed in India, using artificial concrete armour units have stood well against the fury of waves. However, there are few examples of damages to the breakwaters during the severe cyclonic wave conditions. The design aspects, site conditions, constraints, and the performance of artificial concrete units have been discussed in the paper. It is observed that selection of design wave condition, packing density, placing method, slope, and proper toe-berm are important aspects in the design and construction of rubblemound breakwaters with artificial concrete armour units.
\end{abstract}

Keywords: Harbour, Breakwater, Rubblemound, Armour Units, Design Wave, Tetrapods, Accropode, Dolos 
Cite this Article: Apurva M. Kudale, M.D. Kudale, and P. B. Kulkarni, Performance of Concrete Armour Units of Breakwaters in India - A Review, International Journal of Civil Engineering and Technology (IJCIET), 12(6), 2021, pp. 54-66. https://iaeme.com/Home/issue/IJCIET?Volume $=12 \&$ Issue $=6$

\section{INTRODUCTION}

Breakwaters are the structures constructed to protect coastal harbour facilities from the hostile forces of ocean waves and to provide tranquil conditions for the berthing operations of ships. Various types of breakwater structures are rigid, semi-rigid and flexible. Flexible rubblemound structures are commonly used for breakwater construction. A breakwater built as a rubblemound structure is constructed by placing stones of various sizes, layer by layer, comprising a bedding layer, core, secondary layer protected by an armour layer and a toe to prevent slippage of armour units. Armour layer of rubblemound breakwater consists of selected units of quarry stones, if available in the required size and quantity; otherwise, specially designed concrete armour units are used. Better interlocking property of the artificial concrete armour units makes it possible to use armour units lighter than the required quarry stones.

The stability of the rubblemound under wave attack is important aspect in the design of rubblemound breakwaters. The other aspects of the effect of waves on rubblemound are wave run-up, overtopping, reflection and transmission. The stability of rubblemound breakwaters depends primarily upon the stability of individual armour units on its seaward slope. As such, a major aspect in the design is the optimum weight of the armour units on the seaward slope, required to withstand the design waves. Studies have been reported on the hydraulic stability of individual armour units on the seaward slope and empirical formulae are available for the estimation of the optimum weight (Shore Protection Manual, SPM, 1984) [1]. The present design practices of rubblemound breakwaters and seawalls are based on hydraulic model tests in wave flumes to confirm the conceptual design.

A variety of shapes of the concrete armour units have been used in the seaward armour layers of the rubblemound breakwaters. A few of them are Cubes, Tetrapods, Tribars, Hexapod, Akmon, Stabit, Dolosse etc. Typical artificial concrete armour units are shown in Fig. 1. More recently developed blocks are Accropode, Core-loc and X-Blocks. The hydraulic stability of armour units on the seaward face of the breakwaters to withstand design wave conditions not only depends on its weight, but also upon shape, interlocking, specific weight, slope of the structure, number of layers, method of placement, packing density, location (trunk or roundhead), type of waves (breaking or non-breaking) etc. The "Stability Coefficient" $\left(K_{D}\right)$, claimed by the Inventors of different types of armour blocks, which depend on these factors, has been always a controversial issue. As such, hydraulic stability tests in the model either in a 2-D wave flume or a 3-D wave basin become inevitable for the design of the rubblemound structures in which site-specific conditions are correctly simulated.

In India, rubblemound breakwaters have been adopted for the most of the major and minor ports. Quarry stones / rocks as well as artificial concrete blocks such as Tetrapods, Dolosse and Cubes are common armour units used in India for the rubblemound breakwaters and seawalls. These concrete units are to be used in double layer in the armour. Development of deep-water ports in India has necessitated the designs involving lesser costs. As such, single layer armour units like Accropode and Core-loc have also been used for a few breakwaters. Tetrapods are more popular in India in comparison with the other armour units. Rubblemound breakwaters constructed using artificial concrete armour units have stood well against the fury of waves. However, there are few examples of damages to the breakwaters during the severe cyclonic wave conditions. The design aspects, site conditions, constraints, and the performance of artificial concrete units have been discussed in the paper. 


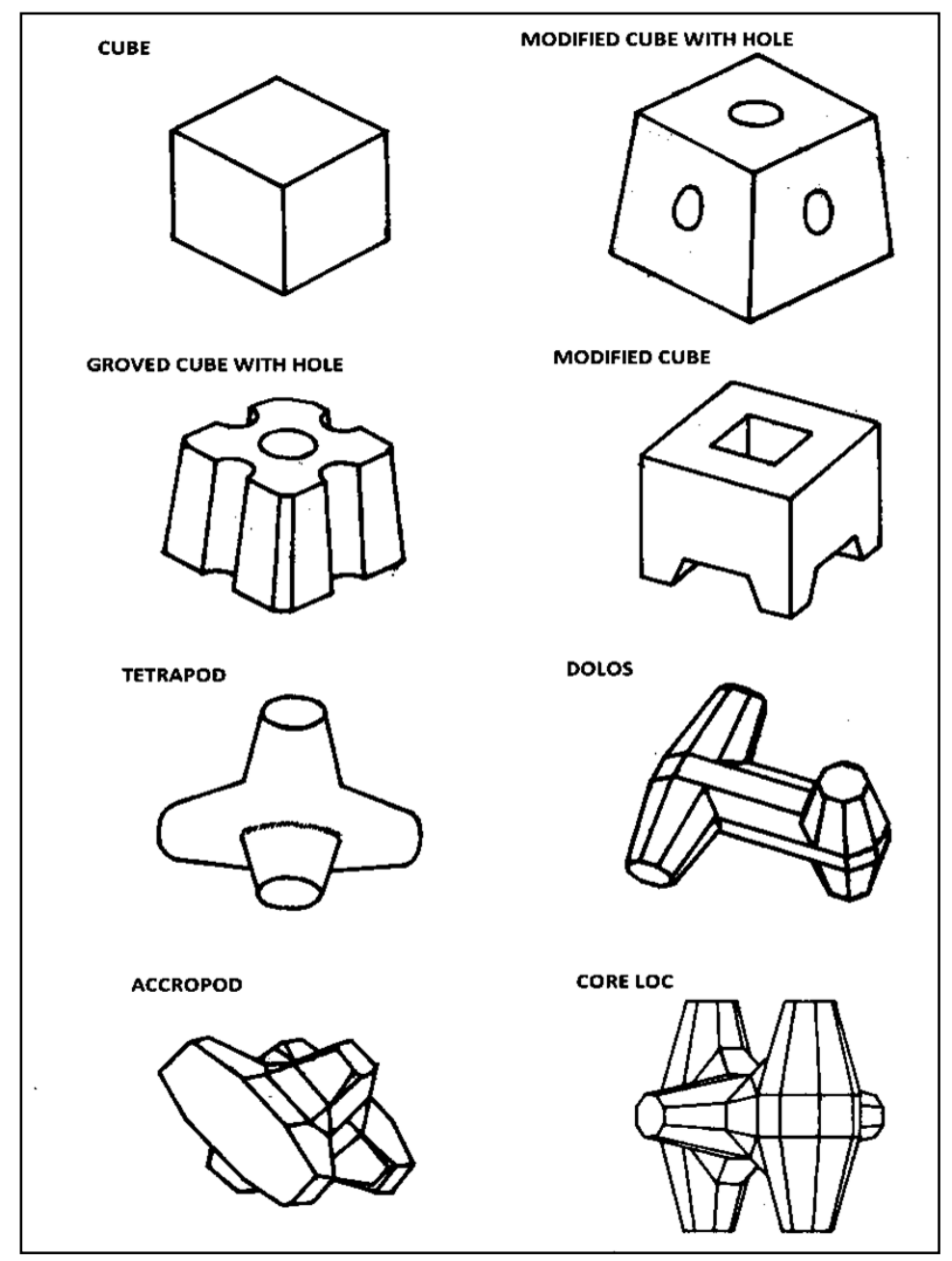

Figure 1 Commonly used Artificial Concrete Armour Units

\section{DESIGN OF RUBBLEMOUND BREAKWATERS}

The design of breakwaters is primarily controlled by wave-structure interaction. The cost of the breakwater is generally high and it increases rapidly with the water depth. As such, the water depth is also an important parameter in the design. The other important aspect in deciding the layout of the breakwater is the influence on currents and sediment transport. The hydraulic aspects of the wave-structure interaction are run-up, run-down, internal flow, overtopping, wave transmission, wave reflection and the hydrodynamics related to armour layer stability.

Hydrodynamic forces induced by the wave action act on the armour units in the cover layer. The 'hydraulic stability' of the armour layer ensures 'no movement / displacement' of armour units on the slope of the breakwater. The other type of stability is the 'structural stability' of the armour units and it includes the stability of the units to resist the stresses induced during casting, placement and displacement. The stability of the rubblemound breakwater mainly depends on the hydraulic stability of individual armour units on the seaward slope. Empirical formulae such as Hudson formula (SPM, 1984) [1] and Van der Meer formula (Van der Meer, 1994) [2] are used for the estimation of minimum weight. The present practice followed by the designers of rubblemound structures is to evolve the conceptual design by empirical formulae, and to confirm it by hydraulic model tests in the wave flumes. A review of the present practices in the design of rubblemound breakwaters is well described by Apurva Kudale et al (2018) [3]. A few numerical models have also been developed for the design of rubblemound structures (Ref. Kudale et al, 1996) [4]. 


\section{HUDSON'S FORMULA}

Hudson formula (SPM 1984) [1] is widely used for estimating optimum weight of armour unit, because of its simplicity. The formula is based on hydraulic model studies carried out at US Army Corps of Engineers, Waterways Experiment Station.

$$
\mathrm{W}=\frac{\mathrm{w}_{\mathrm{r}} \mathrm{H}^{3}}{\mathrm{~K}_{\mathrm{D}}\left(\mathrm{S}_{\mathrm{r}}-1\right)^{3} \operatorname{Cot} \theta}
$$

Where,

$$
\begin{array}{ll}
\mathrm{W} & =\text { Weight of armour units }(\mathrm{kg}) \\
\mathrm{W}_{\mathrm{r}} & =\text { Unit weight of armour block }(\mathrm{kg} / \mathrm{cum}) \\
\mathrm{H} & =\text { Design wave height }(\mathrm{m}) \\
\mathrm{S}_{\mathrm{r}} & =\text { Specific gravity of armour units } \\
\theta & =\text { Angle of breakwater slope } \\
\mathrm{K}_{\mathrm{D}} & =\text { Stability coefficient }
\end{array}
$$

Stability coefficient $\left(K_{D}\right)$ varies with the type of armour unit. It takes into account roughness, Sharpness of edges, quality of interlocking etc. $\mathrm{K}_{\mathrm{D}}$ values were established for stones and artificial concrete armour units viz. Tetrapods, Tribars etc. These values were worked out for no damage condition (i.e. the damage to the armour units less than $1 \%$ ). $\mathrm{K}_{\mathrm{D}}$ values have been evolved by number of laboratories through scaled model tests. These laboratory studies to evaluate $\mathrm{K}_{\mathrm{D}}$ have considered waves of constant period. The significant wave height $\mathrm{H}_{\mathrm{s}}$ is considered as design wave height to be used for $\mathrm{H}$ in above equation.

\subsection{Thickness of Armour Layer and Placing Density}

The thickness of the cover layer and the number of armour units required for unit surface area are determined from the following formulae:

$$
r=n K \Delta\left[\frac{W}{w_{r}}\right]^{1 / 3}
$$

Where,

$\mathrm{r} \quad=$ Average layer thickness $(\mathrm{m})$

$\mathrm{n} \quad=$ No. of armour units in thickness of cover layer

$\mathrm{K}_{\Delta} \quad=$ Layer coefficient

$\mathrm{W}=$ Mass of armour unit in cover layer $(\mathrm{kg})$

$\mathrm{W}_{\mathrm{r}} \quad=$ Mass density of armour unit $(\mathrm{kg} / \mathrm{m} 3)$

The placing density, (i.e., number of units to be used in $100 \mathrm{~m}^{2}$ surface area) is given by

$$
\frac{N r}{A}=n K \Delta\left[1-\frac{P}{100}\right]\left[\frac{w r}{W}\right]^{2 / 3}
$$

Where,

$\mathrm{N}_{\mathrm{r}} \quad=$ armour units on sloping surface

A $=$ Surface area,

$\mathrm{K}_{\Delta} \quad=$ Layer coefficient

$\mathrm{P} \quad=$ Average porosity of a cover layer 


\section{ARTIFICIAL CONCRETE ARMOUR UNITS}

Prior to 1950s, the breakwaters were built in relatively shallower waters and the natural stones were used as armor units. As the constructions moved into deeper waters, the requirement of heavy armor weights kept increasing and such large stones were uneconomical to quarry and transport. Consequently, many different shapes of concrete blocks were developed as armor units for rubble structures. The major advantage of concrete armor units is that they usually have a higher stability coefficient values and thus permit the use of lighter weight of armor units on steeper structure slopes. Some of the concrete armor units, which are commonly used for the construction of rubblemound breakwaters, are listed in Table 1 (Ref. SPM, 1984) [1].

Table 1 Types of Armour Units

\begin{tabular}{|c|c|c|}
\hline \multirow{2}{*}{ Name of Unit } & \multicolumn{2}{|c|}{ Development of Unit } \\
\hline & Country & Year \\
\hline Akmon & The Netherlands & 1962 \\
\hline Binnie block & England & 1962 \\
\hline Bipod & The Netherlands & 1962 \\
\hline Cube & - & - \\
\hline Cube modified & United States & 1959 \\
\hline Dolos & South Africa & 1968 \\
\hline Quadripod & United States & 1959 \\
\hline Rectangular block & - & - \\
\hline Tetrapod & France & 1950 \\
\hline Tribar & United States & 1958 \\
\hline Tripod & Netherlands & 1962 \\
\hline Accropode & France & 1981 \\
\hline Core-loc & USA & 1992 \\
\hline X-bloc & The Netherlands & 2001 \\
\hline
\end{tabular}

These concrete blocks initially were cubic or rectangular shaped (Fig. 1). However, cubic or rectangular blocks were found to be less stable than natural rock of same weight. However, special shapes have proved advantageous when used as primary armour units. One of the earlier non-block concrete armour units were the Tetrapods, developed in France in 1950. The concepts of interlocking, voids, and roughness were the primary criteria in the development of tetrapod. The effectiveness of these factors can be seen from the fact that the Tetrapod has a $\mathrm{K}_{\mathrm{D}}$ value of 8.0 compared to a $K_{D}$ value of 4.0 for natural rock (non-breaking wave conditions). This indicates that the Tetrapod weight would be nearly half that of the natural rock under identical design conditions. Since the development of the Tetrapod, many different shapes of concrete blocks have been developed with the primary aim of having as high $\mathrm{K}_{\mathrm{D}}$ values as possible. Even though, Tetrapod is the most popular and widely used armour unit.

The armour unit Dolos, developed by Merrifield in South Africa in 1968 probably represents the peak of the concept of interlocking and voids. However, the heavy dependence on interlocking brought new problem of high vulnerability of breakage of the slender outstanding legs under wave action and even during placement. Once the unit breaks, interlocking is lost and the unit behaves as one with a considerably lower $\mathrm{K}_{\mathrm{D}}$ value i.e. inadequate weight. M/s. Sogreah, France (developers of Tetrapod armour unit) introduced a new armour unit, the ACCROPODE, which is claimed as high-performance economic unit. The Accropode with its specially designed shape (Figure 1), is recommended to be used in a single layer on steeper slope while other units like the Tetrapod or Dolos, require a two-layer placement to achieve their efficiency. The Accropode concept avoids slender outstanding legs. The stability co-efficient $\left(\mathrm{K}_{\mathrm{D}}\right)$ initially claimed by the Inventors of Accropode was very high (above 30). However, considering various uncertainties, the recommended $K_{D}$ values are 12 
and 15 for breaking and non-breaking wave conditions. WES, USA in 1992 has introduced the concrete armour unit called 'Core-loc'. The Core-locs are similar to the Accropodes and are to be laid in a single layer. The stability claimed for Core-loc is higher than that for the Accropode.

The stability of artificial armour blocks Tetrapod, Dolos and Accropode has been assessed under random sea wave conditions (Gadre et al, 1991) [5], (Vaidyaraman et al, 1995) [6]. The equivalent design wave height taken in the design formula for representing the random wave train was the significant wave height $\left(\mathrm{H}_{\mathrm{S}}\right)$. However, the studies by Kudale et al (2015) [7] revealed that this equivalent design wave height shall be $\mathrm{H}_{1 / 10}$ (average of highest one-tenth of the waves) instead of $\mathrm{H}_{\mathrm{S}}$. The studies on Dolos armour units with different packing densities (i.e., number of units per $100 \mathrm{~m}^{2}$ surface area) indicated that the lower packing density as well as higher packing density affects adversely on the stability of armour layer (Gadre et a., 1986) [8]. The importance of simulating exact seabed slope in front of the model of rubblemound structure in the wave flume was enumerated, by assessing the stability of armour stones with different seabed slopes (Sarma and Kudale, 2011) [9].

\section{INDIAN SCENARIO}

As stated earlier, most of the breakwaters constructed for various Indian Ports are rubblemound structures with natural stones or Tetrapods in the armour. At some places concrete cubes and Dolosse have also been used. More recently, single layer armour units viz. Accropode and CoreLoc are also utilized at few harbours (Kudale et al, 2018) [10].

Some of the breakwaters, and their performance is discussed in the succeeding paragraphs.

\subsection{Breakwaters at Visakhapatnam Port}

Visakhapatnam Port was commissioned in 1976 and consists of the Inner and Outer Harbour. The Outer Harbour is formed by construction of three breakwaters viz. South breakwater, North Breakwater, and East Breakwater. Large concrete cubes have been used in the armour of the main breakwaters. These cubes are having holes to release the wave energy as well as to facilitate lifting and placing of blocks. The south breakwater lies in the water depth of about 17 $\mathrm{m}$ and was designed to withstand the waves of the order of $7 \mathrm{~m}$ in height. The weight of the concrete cubes is about 50 tonne and these blocks were provided on seaside slope, crest, and the leeside slope of the breakwater (Photo. 1). The roundhead of the south breakwater consists of 35 tonne Dolosse units in the armour.

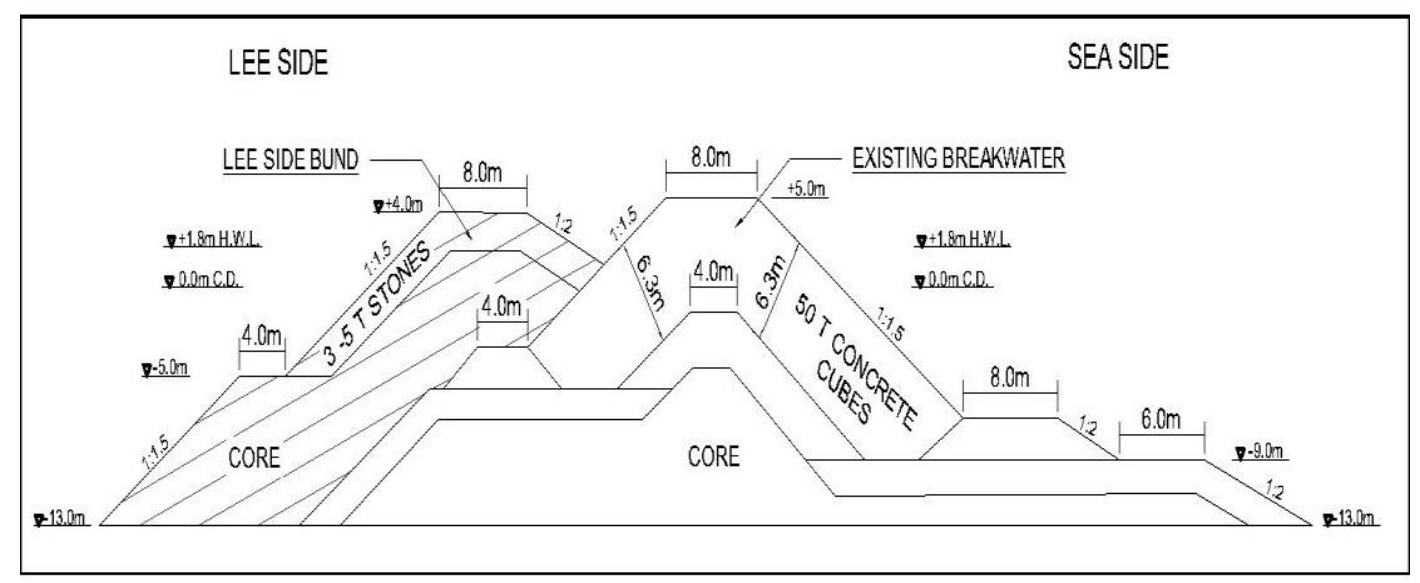

Figure 2 Modification to the Breakwater to Reduce Wave Transmission

The breakwater had withstood well against the wave attack except some settlement of the blocks. However, after the development of an Off-Shore Tanker Terminal (OSTT) on the leeside of the existing south breakwater, difficulties were faced in berthing operations of tankers 
at the OSTT due to wave disturbance. The root cause of the disturbance was the transmission of the waves through the breakwater because of the voids in the large armour units. A rubble apron was provided on the leeside of the breakwater (Fig. 2) based on the hydraulic model studies in the wave flume (Poonawala et al, 2001) [11], which has successfully reduced wave disturbance in front of the OST Terminal on the leeside.

\subsection{Breakwater at Veraval Fisheries Harbour}

Veraval is a fisheries harbour along the West Coast of India in Saurashtra, formed by two breakwaters, the eastern breakwater (440 m long) and the western breakwater (334 m long). The western breakwater was originally constructed using 10.5 t Dolos blocks in the armour layer on 1:2 slope. This breakwater located in an average water depth of $9 \mathrm{~m}$ was designed for $6.35 \mathrm{~m}$ high waves. The breakwater suffered major damage during severe storm conditions in 1984. In view of the occurrence of large storm waves of the order of $8 \mathrm{~m}$, design wave height was modified as $7.0 \mathrm{~m}$ (Significant wave height, $\mathrm{H}_{\mathrm{s}}$ ). Furthermore, it was decided to use Tetrapods instead of Dolosse, since the multilegged, slender Dolos blocks had shown damages due to breakage of slender legs and thereby loss of interlocking, which led to damage to the breakwater. A conventional rubblemound breakwater needed $25 \mathrm{t}$ Tetrapods in the armour (Fig. 3a) for the design wave height of $7.0 \mathrm{~m}$. An alternative design was sought due to various constraints to handle heavy tetrapods of $25 \mathrm{t}$ weight, and high cost of construction as well as difficulties in removing debris of the damaged breakwater. Utilization of the existing mound as a toe-berm was considered (Poonawala et al, 2001) [12] and it was covered with 3 to $5 \mathrm{t}$ stones to form a $20 \mathrm{~m}$ wide toe-berm. In the modified design, $12 \mathrm{t}$ Tetrapods were used in the armour on 1:1.5 slope (Fig. 3b). This solution avoided the use of heavy armour units and heavy equipment thereby reducing the cost of construction. The rehabilitated breakwater has withstood very well against severe wave conditions, including the severe storm of June 1998, which hit the Saurashtra Coast (Photo. 2).

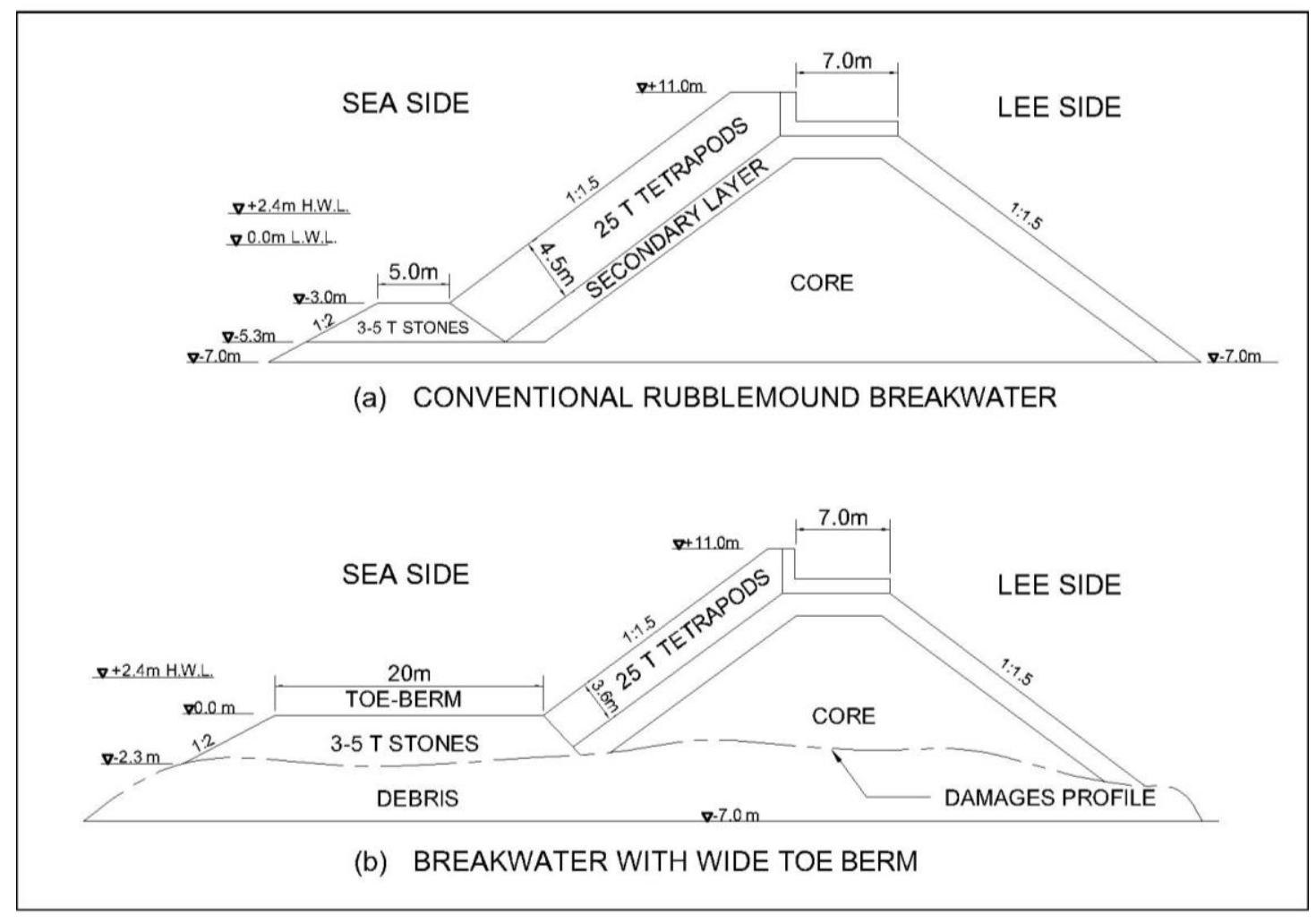

Figure 3 Comparison of Conventional Rubblemound Breakwater and Breakwater with Wide Toe-Berm 


\subsection{Breakwater at Porbandar Port}

Porbandar is another important intermediate port on the Saurashtra coast. The Port, which was commissioned in early eighties, consists of a $2.6 \mathrm{~km}$ long rubblemound breakwater. Tetrapods of $12 \mathrm{t}$ weight were used in the armour of the breakwater, considering the design wave height of $6 \mathrm{~m}$. A severe cyclone hit the Porbandar coast on 9 June, 1998. The rubblemound breakwater of Porbandar Port suffered devastating damage during the cyclone. Out of the total length of $2.6 \mathrm{~km}$ of the breakwater, about $600 \mathrm{~m}$ length of the breakwater from the seaward tip was totally damaged.

The hindcast storm wave data indicated a 100-year return period wave height of about $7 \mathrm{~m}$ at Porbandar. The breakwater was redesigned for this wave condition (Poonawala et al, 2001) [12]. Similar to Veraval breakwater, a solution with a wide toe-berm was evolved. The rehabilitated breakwater with $15 \mathrm{t}$ tetrapods in the armour layer and a $20 \mathrm{~m}$ wide toe-berm of 2 to $3 \mathrm{t}$ stones has withstood the monsoon waves successfully for the past couple of years (Photo. $3)$.

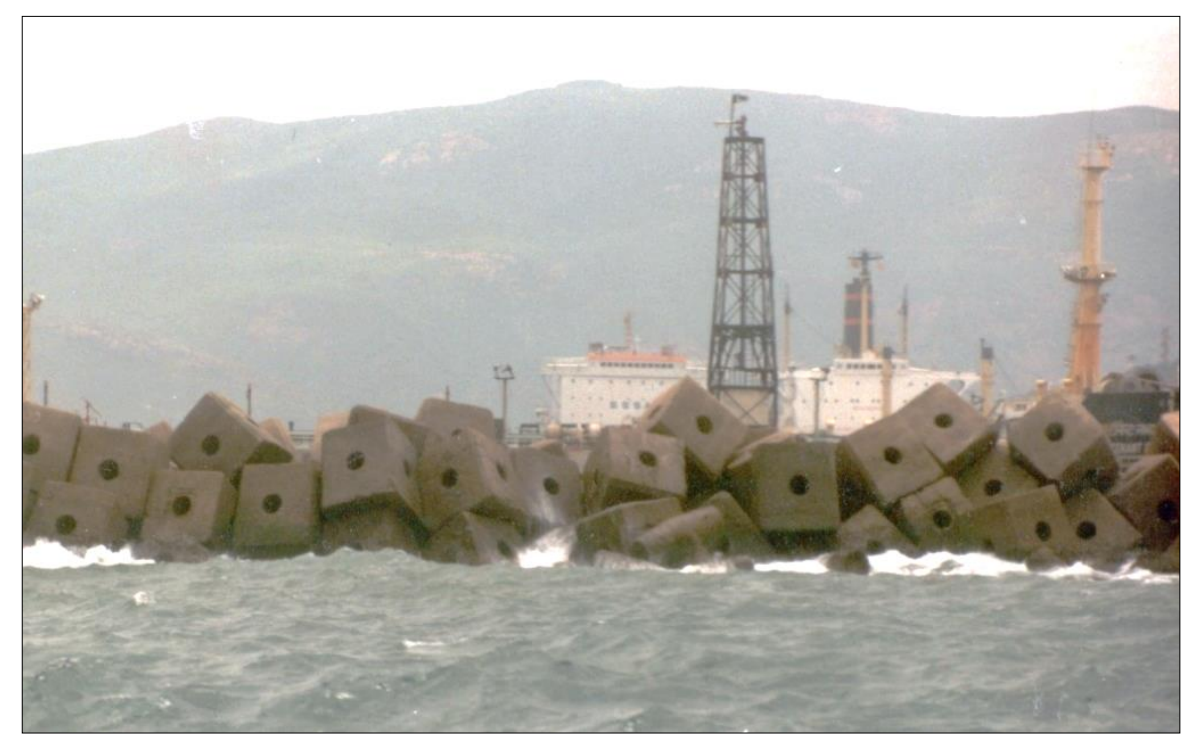

Photo 1: Modified Cubes in Visakhapatnam South Breakwater
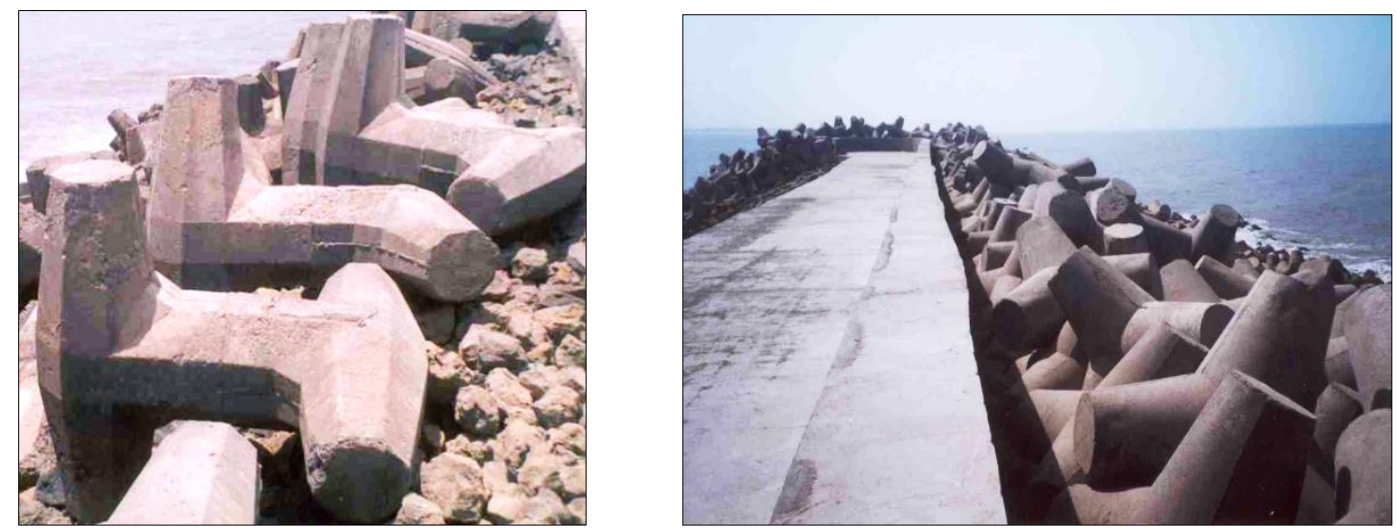

Photo 2: Dolos at Veraval Breakwater replaced with Tetrapods 


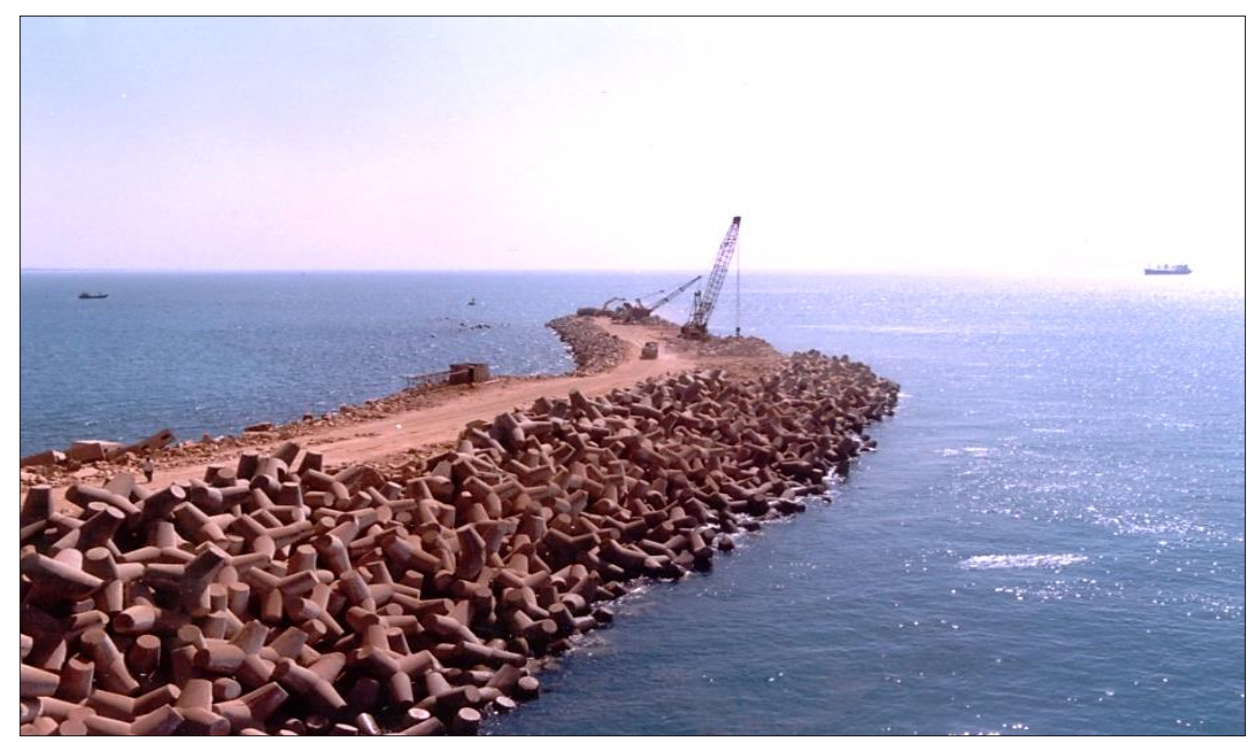

Photo 3: Tetrapods being placed at Porbandar Breakwater

\subsection{Breakwater at Mul-Dwarka Port}

A captive port has been developed by M/s. Gujarat Ambuja Cements Ltd (GACL) at MulDwarka on the Saurashtra Coast to cater for bulk cement carriers. In the first phase of development, a cement loading terminal was constructed to cater for 2500 DWT bulk cement carriers in the harbour, which is protected by a $420 \mathrm{~m}$ long rubblemound breakwater. Port facility was expanded to cater for 15000 to 40000 DWT vessels In the second phase of development. The breakwater was extended by about $600 \mathrm{~m}$ length to accommodate larger vessels at a deep-water berth operative for about 300 days in a year.

The first phase breakwater extends up to $-6.5 \mathrm{~m}$ contour, designed for $5.0 \mathrm{~m}$ waves and consists of $14 \mathrm{t}$ Tetrapods on 1:1:5 armour slope. Similarly, the breakwater extension of $600 \mathrm{~m}$ length in the second phase, lies at $-8.0 \mathrm{~m}$ contour, designed for $7.0 \mathrm{~m}$ waves and consists of 22 $\mathrm{t}$ tetrapods in the armour on 1:2 slope (Fig. 4). Tetrapods of $30 \mathrm{t}$ weight are used on 1:2 slope in the armour layer of the roundhead at -12 m contours. (Poonawala et. al. 1997) [13].

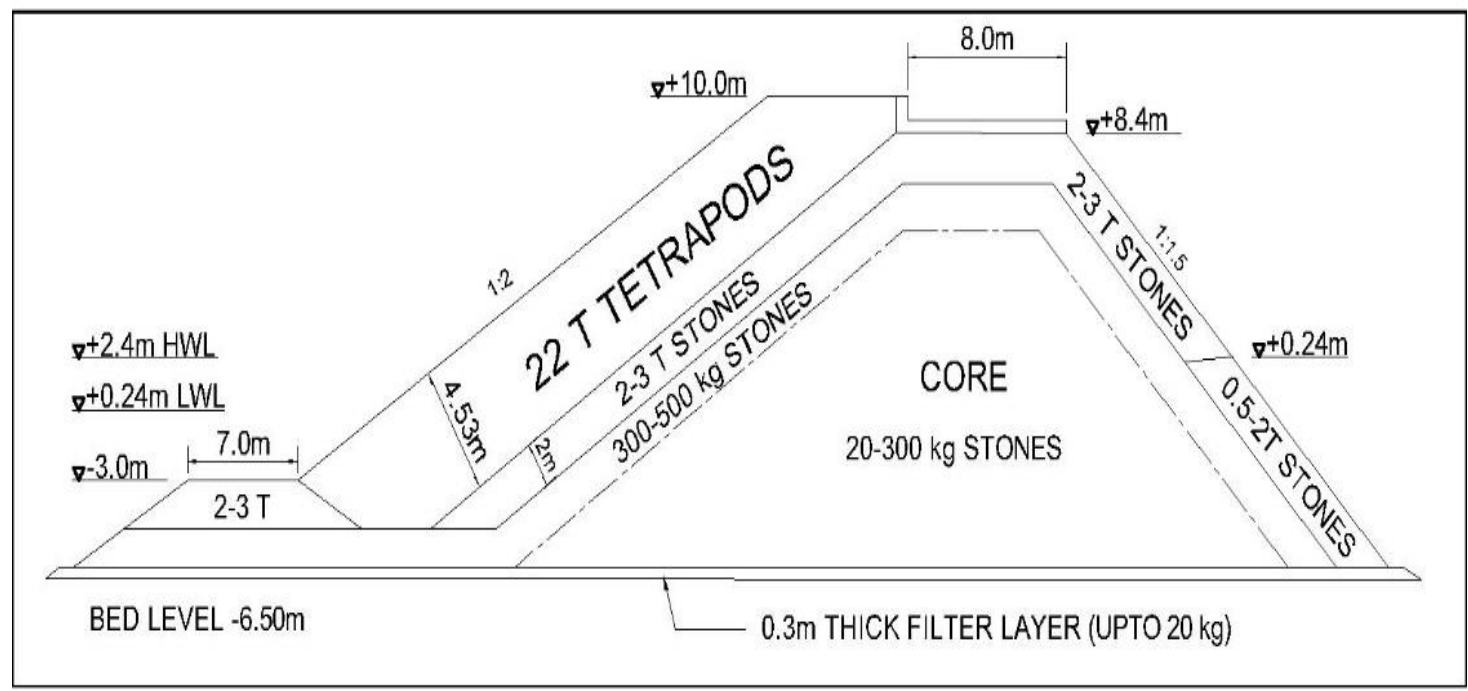

Figure 4 Breakwater of Captive port at Mul-Dwarka

A severe cyclonic storm passed through the area in June 1996, and waves of the order of 7 $\mathrm{m}$ (which was considered as the design wave condition) were visually observed at the site by 
the Port Engineers during this storm. The breakwater withstood the severe wave conditions without any damage.

\subsection{Breakwater at Kakinada Port}

An intermediate port of Kakinada is situated on the east coast of India in Kakinada Bay. The port consists of a $1200 \mathrm{~m}$ long Island type of breakwater. The full length of the breakwater lies at $-5 \mathrm{~m}$ contour. The breakwater has been designed as an overtopping structure to withstand waves unto $6 \mathrm{~m}$ height and consists of $14.4 \mathrm{t}$ Tetrapods in the seaside armour, crest and the leeside armour (Fig. 5). The roundheads of the breakwater are constructed using $19.2 \mathrm{t}$ Tetrapods in the covering layer. The seabed at Kakinada consists of soft marine clay and the foundation conditions for the breakwater are poor. In order to improve the foundation conditions, the soft clay was layer was removed and filled with sand before the construction of breakwater. The port was commissioned in 1994 and since then the Island type of breakwater has been functioning satisfactorily under the hostile wave conditions on the East Coast of India.

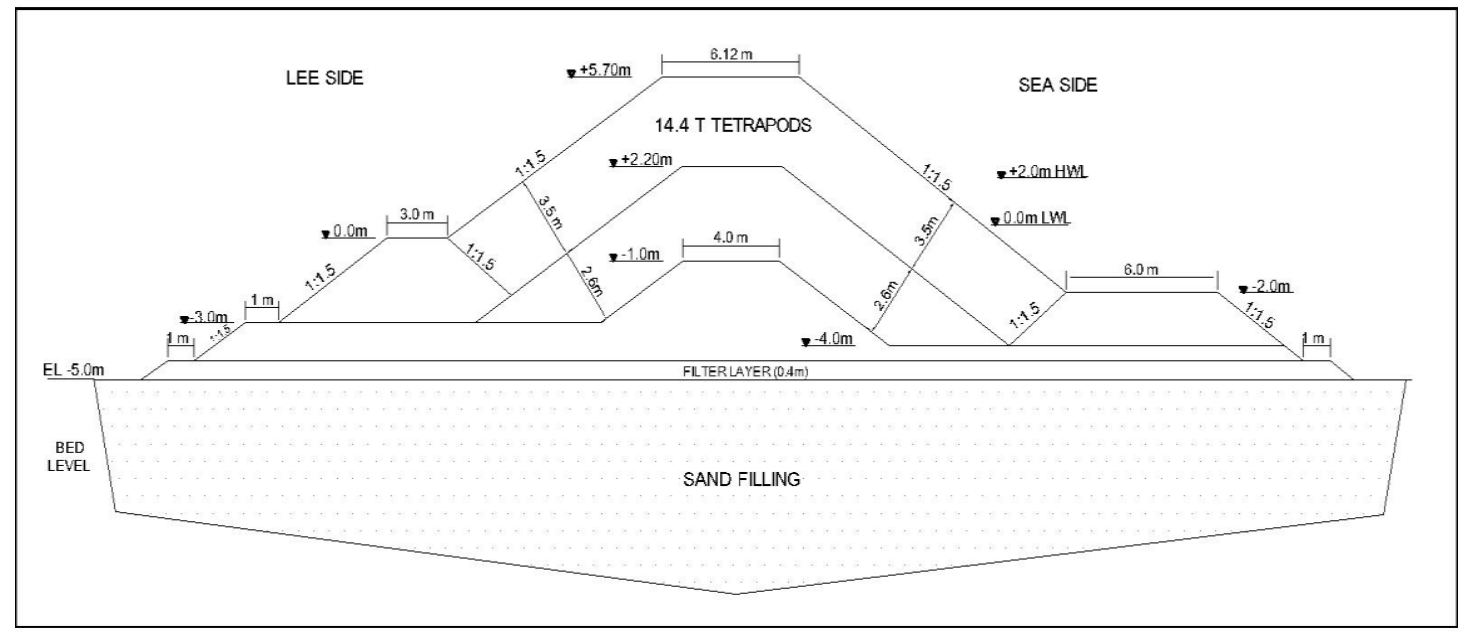

Figure 5 Island Type Breakwater at Kakinada

\subsection{Offshore Breakwater at Mandwa, Maharashtra}

A passenger water transport terminal has been developed by Maharashtra Maritime Board (MMB) at Mandwa near Alibag to cater for the transport between Mumbai and mainland. A $360 \mathrm{~m}$ long offshore breakwater has been provided for giving protection to passenger terminal (Fig. 6).

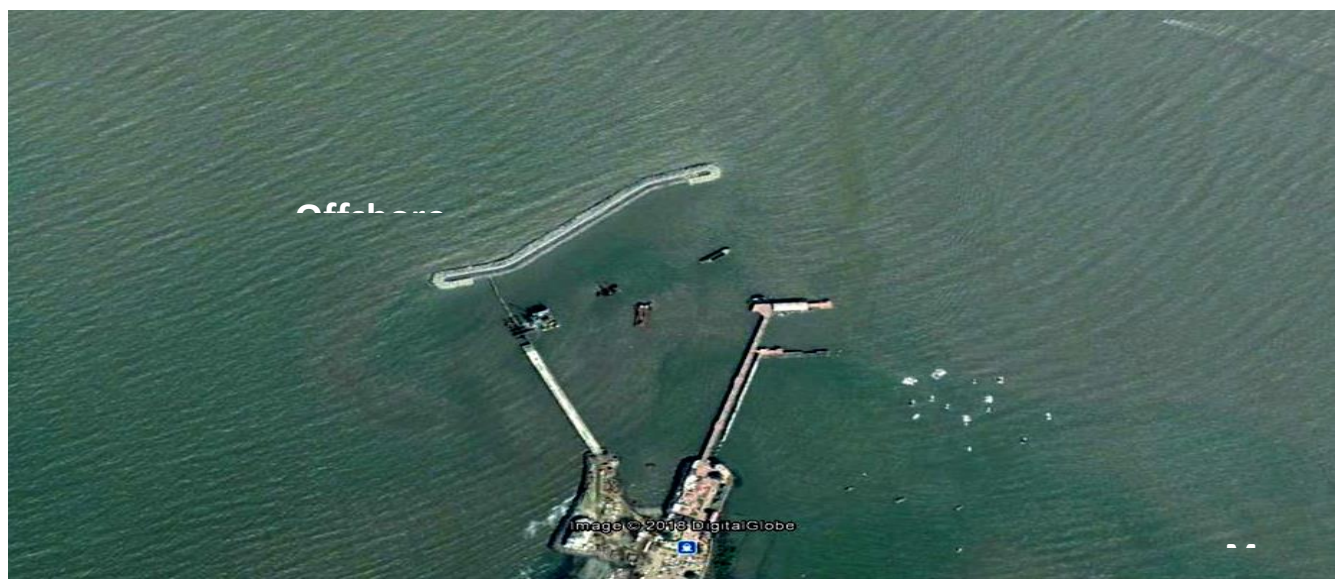

Figure 6 Imagery of Mandwa Port, Maharashtra 
The tidal range of more than $5 \mathrm{~m}$ at the location was a major challenge in designing the terminal and breakwater. Siltation due to tidal currents was another concern, which has been tackled by adopting offshore breakwater instead of shore connected breakwater. A typical shape has been provided to guide the tidal currents. The trunk portion of offshore breakwater in a water depth of about $7 \mathrm{~m}$ consists of $8 \mathrm{t}$ tetrapods in the armour and the roundheads are consisting of $10 \mathrm{t}$ Tetrapods in the armour layer (Fig 7). The breakwater was completed in May 2017. Barge mounted cranes were exclusively utilized for the construction. The offshore breakwater is stable and providing satisfactory tranquil conditions for the passenger terminal.

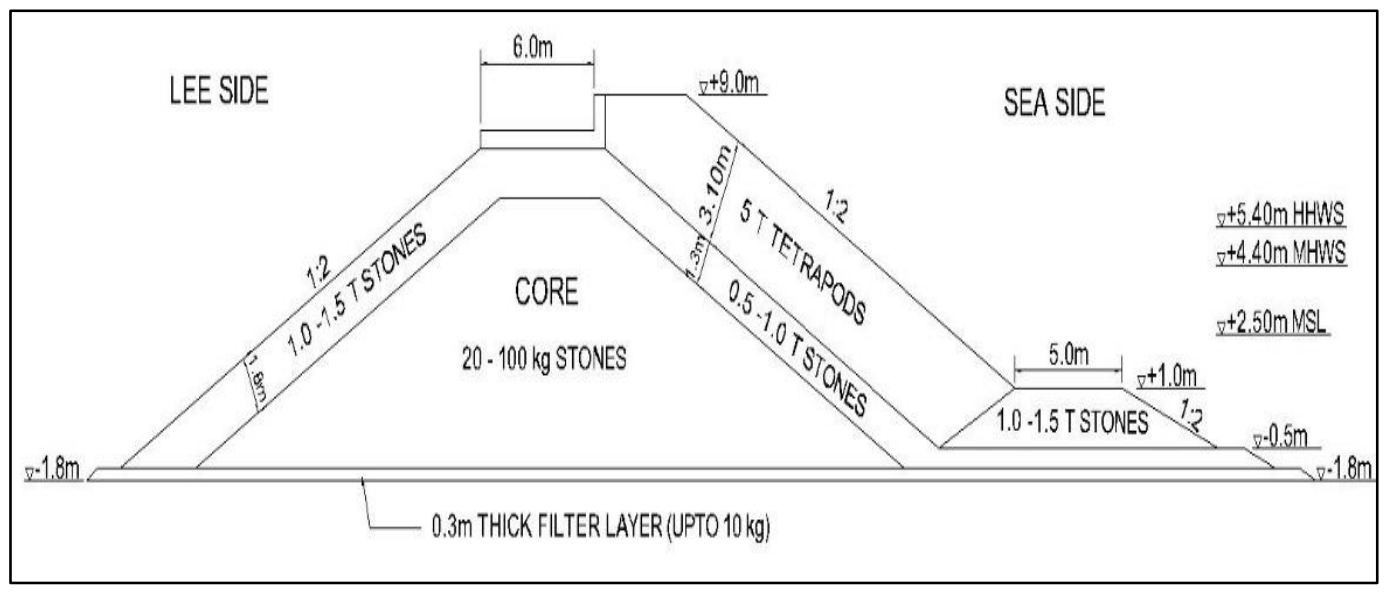

Figure 7 Offshore Type Breakwater at Mandwa

\subsection{Other Breakwaters}

The outer arm of the breakwater at Chennai port consists of 15 tonne Tetrapods in the armour layer. The breakwaters at Chennai port have been performing satisfactorily over the years and no significant damage has been reported so far. The Tuticorin breakwater is one of the longest breakwaters comprising quarry stones of 6 tonne in the armour layer. The damage to the crest of the breakwaters has been repaired using concrete cubes. The breakwaters at the major Ports of Paradip and New Mangalore consist of natural stones in the armour layer. In case of New Mangalore Port, a typical wide cross-section of the breakwater having berms at different levels on the either sides have been used to cope up with the poor soil conditions at the site. The breakwater at Mormugao Port is the oldest breakwater in India. It is a vertical type of breakwater constructed using 15-20 tonne rectangular concrete blocks. Due to deterioration of concrete over the years, the structure was endangered. In order to ensure stability of the breakwater against monsoon waves, the breakwater was strengthened by placing concrete blocks in a slope on the seaside.

A $490 \mathrm{~m}$ long breakwater has been constructed by Andman and Lakshdweep Harbour Works, for the development of port facilities at Mus, Car-Nicobar Island. The breakwater has been designed to withstand significant wave height of $5 \mathrm{~m}$ and consists of $8 \mathrm{t}$ Tetrapods in the armour on 1.1.5 slope. The roundhead at $-11 \mathrm{~m}$ contour is constructed using $16 \mathrm{t}$ Tetrapods in the cover layer.

More recently, for the breakwater at Ennore Port, single layer armour units i.e., Accropode have been provided. Also, Accropode armour units are being used for the breakwaters of deepwater ports at Vizhinjam in Kerala and Jaferabad in Gujarat. Another single layer armour unit i.e., Core-Loc has been utilized for breakwaters of the fisheries harbours at Kolachel and Thengapatanam in Tamil Nadu.

Artificial armour units are also utilized in the cover layer of rubblemound seawalls constructed for shore protection. Most familiar example is the Marine Drive seawall at Mumbai 
where $2 \mathrm{t}$ Tetrapods are used on 1:1.5 slope of the armour. The parapet wall has been designed with a peculiar shape so that it diverts the splash of water back into the sea.

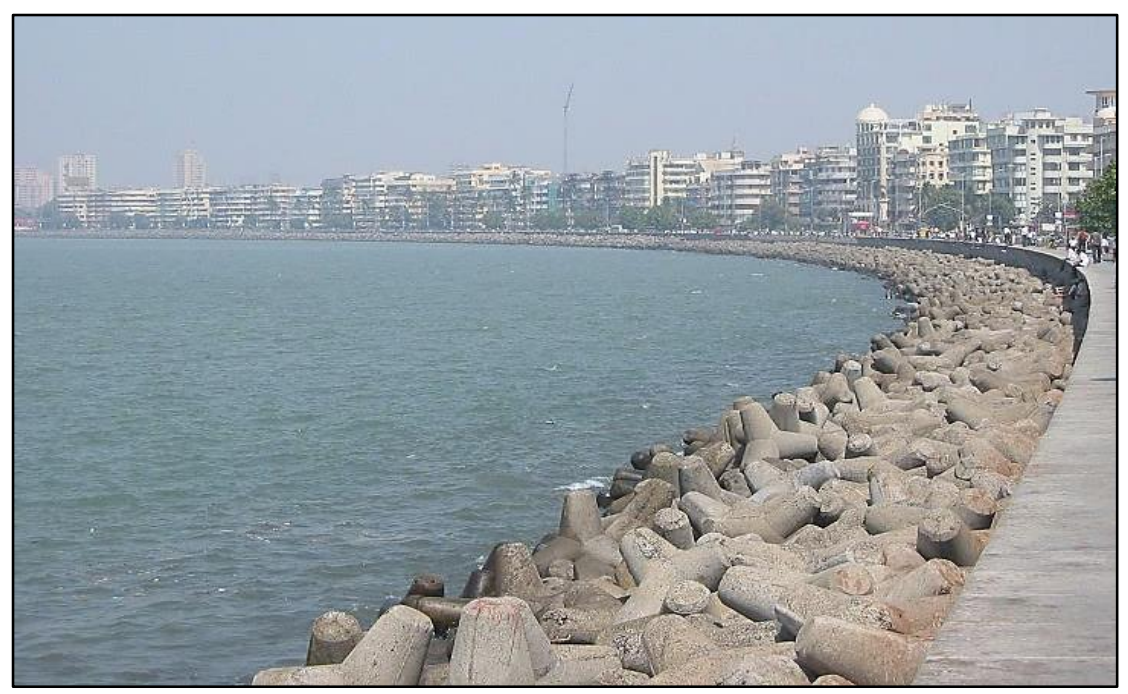

Photo 4 Seawall at Marine Drive, Mumbai

\section{CONCLUDING REMARKS}

From the review study of artificial concrete units of the rubblemound breakwaters in India, the following broad conclusions are drawn:

- Empirical formulae as well as the stability co-efficient $\left(\mathrm{K}_{\mathrm{D}}\right)$ are available for determining the weight of the armour units. However, the breakwater cross-sections need to be tested in wave flume / basin for their hydraulic stability.

- Packing density of armour units and slope of the armour layer are important aspects in the design of rubblemound breakwaters. It is necessary to ensure proper execution of these parameters during construction of the breakwaters.

- Tetrapod has proved its utility in breakwaters in India and is presently the most popular artificial concrete armour unit.

- Armour units like Accropode, Core-loc appear to be promising for the construction of breakwaters in the deeper waters. Because of their special feature of 'single layer construction', about $40 \%$ saving in the cost of the concrete can be achieved. However, hydraulic stability of these blocks largely depends on the appropriate 'placing of the blocks'. As such, highly skilled construction technique and expertise needs to be utilised.

- The south breakwater at Visakhapatnam port has showed that, in addition to the hydraulic stability of rubblemound breakwater, the transmission behaviour shall also be studied while designing it so as to ensure proper tranquillity conditions on the leeside of the breakwater.

- A concept of a Rubblemound Breakwater with Wide Toe-Berm reduces the required armour unit weight in the conventional breakwater. It enables ease in construction, saving in concrete, saves the use of heavy equipment and finally overall savings in the cost of construction. This concept is especially useful in rehabilitation works of rubblemound breakwaters, where the damaged mound can be utilised as wide toe-berm.

\section{ACKNOWLEDGEMENT}

The authors are grateful to the Scientists of Central Water and Power Research Station (CWPRS), Pune for availing the research publications. 


\section{REFERENCES}

[1] Shore Protection Manual, (SPM), (1984), U.S. Army Corps of Engineers, Coastal Engineering Centre, U.S. Government Printing Office, Washington D.C., U.S.A.

[2] Van der Meer J.W. (1988), "Rock Slopes and Gravel Beaches under Wave attack", Publication No. 396, Delft Hydraulics, The Netherlands.

[3] Kudale Apurva M., Dr. Sohoni V. S., Dr. Patil B. M. and Mahalingaiah A. V. (2018), Present Practices in Design of Rubblemound Breakwaters for Coastal Harbours - A Review", International Journal of Current Engineering and Technology (IJCET), Vol.8, No.3.

[4] Kudale M.D., Kobayashi N. (1996), "Hydraulic Stability Analysis of Leeside Slopes of Overtopped Breakwaters", 25th Int. Conf. on Coastal Engineering, (ASCE), Orlando, Florida, U.S.A.

[5] Gadre M.R., Poonawala I. Z. and Kudale M.D. (1991), "Stability of Tetrapods Under Random Wave Attack", Third Int. Conf. on Coastal \& Port Engineering in Developing Countries, Mombasa, Kenya.

[6] Vaidyaraman P. P., Poonawala I. Z., Kudale M. D., Purohit A. A. (1995), "Stability of Accropode Armour Units under Breaking Wave Conditions" Fourth International Conference on Coastal and Port Engineering in Developing Countries, Rio de Janeiro, Brazil.

[7] Kudale M. D., Bhalerao A.R., (2015) "Equivalent Monochromatic Wave Height for the Design of Coastal Rubblemound Structures" - Science Direct, Aquatic Procedia, ELSEVIER Journal Publication, ISSN: 2214-241X, Volume 4 (2015), pp.264-273.

[8] Gadre M.R., Poonawala I.Z. and Kudale M.D. (1986), "Effect of Packing Density of Dolosse on Stability of Armour Layer", Third Indian Conference on Ocean Engineering, IIT, Bombay, India.

[9] Sarma A.V. Sitarama, Kudale M.D. (2011), "Stability of wide toe berm breakwater with varying seabed slope; Journal of Hydraulic Engineering, Indian Society for Hydraulics (ISH), Vol.17 No.2, pp. 43-49.

[10] M. D. Kudale, A. V. Mahalingaiah, B. R. Tayade (2018), "Rubblemound Breakwaters - Indian Scenario", - "Sixth National Conference on Coastal, Harbour and Ocean Engineering (INCHOE-2108)", CWPRS, Pune, India.

[11] Poonawala I.Z., Kudale M.D., Purohit A.A., Kulkarni S.P. and Das A. K. (2001), "Measures to Reduce Wave Transmission through Rubblemound Breakwater - A Case Study", International Conference in Ocean Engineering, IIT, Madras, India.

[12] Poonawala I.Z., Kale A.G., Kudale M.D., Purohit A.A. and Das A. K. (2001) “A New concept of Rubblemound Breakwaters with Wide Toe-Berm", International Conference on Port and Maritime $R \& D$ and Technology, Singapore.

[13] Poonawala I.Z., Kanetkar C. N., Kudale M. D., Vaidya A. M.(Mrs.) (1997) "Hydraulic Model Studies for Captive Port at Mul-Dwarka - A Case Study", -; Second Indian National Conference on Harbour and Ocean Engineering (INCHOE-1997), CESS, Thiruvananthapuram, India. 